\title{
FOLLOW-UP OF PARAPLEGIC PATIENTS AFTER COMPREHENSIVE REHABILITATION
}

By M. Matilde M. Sposito, M.D., ${ }^{1}$ M. Eugenia P. Casalis, M.D., ${ }^{1}$ and I. Ferraretto, M.D. ${ }^{2}$

${ }^{1}$ Associação de Assisténcia à Criança Defeituosa (A.A.C.D.), Rehabilitation Center, Paraplegics Department, P.O. Box 8334, São Paulo, Brasil. ${ }^{2}$ Associação de Assistência à Criança Defeituosa (A.A.C.D.), Rehabilitation Center, Medicai Director, P.O. Box 8334, São Paulo, Brasil.

Summary. One hundred patients from a total of 239 paraplegic patients were surveyed after at least 6 months in community life in order to assess the value of the rehabilitation programme. The patients' average age was 24 years, and the highest neurological level being $T_{I}$. All patients had received intensive care, the average time being 4.7 months. The results were similar to those described in the literature, but the lower socio-economic levels and the absence of comprehensive initial care in general hospitals soon after trauma were negative factors. It is concluded that (I) Brazil requires medical and paramedical staff with specific training for the acute phase in more Rehabilitation Centres; (2) that paraplegics are greatly benefited by a rehabilitation programme; (3) the Brazilian Social Security should sponsor the rehabilitation programme.

Key words: Paraplegic; Rehabilitation; Socio-economic and cultural levels.

\section{Introduction}

THERE Is little awareness in Brazil of the necessary rehabilitation programme for paraplegics, and only a small number of Rehabilitation Centres are available, and these are concentrated in the large urban centres. National statistics for paraplegia are not available.

\section{Method}

One hundred patients out of 239 treated from January 1972 to July I980 under hospital conditions were arbitrarily chosen with the highest neurological level being $\mathrm{TI}_{\mathrm{I}}$, the patient having been discharged from hospital after the rehabilitation programme at least 6 months previously. The information was derived from data from the hospital records, by reexamination and by questionnaire.

\section{Results}

The average age was 24 years and 67 per cent were male. Eighty-seven per cent were caucasion and 62 per cent were unmarried.

Eighty-three per cent of patients had complete lesions with a high incidence at levels T4-T6 and Tro-Ti2. Trauma was the most common cause $(77 \%) ; 47$ per cent were due to car accidents without predominance of sex, age or social class. Among the non-traumatic lesions there were patients with spinal cord cysticercosis and schistosomosis, indicating the socio-economic and cultural level of some of the patients. 


\section{Early Phase of Management}

Patients received care in many different parts of the country, and 55 per cent had a laminectomy. In 2 I per cent of patients there was no orthopaedic or neurosurgical treatment. The high incidence of laminectomy indicates the lack of knowledge of current medical information; especially in many general hospitals.

\section{Complications}

Since the basic principles of the treatment of paraplegic patients are not standardised in Brazil, the incidence of complications is high:

I. Pressure sores. Sixty-eight per cent of patients had pressure sores of which 65 per cent were multiple and 57 per cent needed plastic surgery.

2. Urinary lithiasis. Thirty-five per cent of patients suffered from stone in the urinary tract.

3. Urinary infection. A history of urinary infection was found in 73 per cent of patients of which 60 per cent had positive cultures (above $10^{5} \mathrm{col} / \mathrm{ml}$ ).

4. Associated complications. Sixty-two per cent of the patients had one or more associated complications with a total of i I 5 events mainly urological and orthopaedic.

\section{Delay to Rehabilitation Process}

Only Io per cent of the paraplegic patients were received within the first 30 days and none were received in the first 72 hours. Seventy per cent of those received in the first month were from the medium high social class. Those from low and medium low social classes may only arrive in the centre after months or even years after the onset of the paraplegia.

\section{Hospitalisation}

Whenever possible, the associated complications were treated before hospitalisation in order to reduce the period of rehabilitation (average 4.7 months).

\section{Initial and Final Evaluation}

After hospitalisation, evaluation is carried out by a multi-disciplinary group and an individual programme is provided. In the initial evaluation, 87 per cent of patients were completely dependent in activities of daily living but at the end of treatment 95 per cent were independent.

\section{Braces}

During hospitalisation 87 per cent of patients were equipped with orthotic appliances but following discharge of the 46 patients who could be analysed, I 5 had completely abandoned the use of braces; and I9 patients who continued to use braces had a lesion at TI2 or below. Seventy-five per cent 
of patients were wheelchair dependent as the only means of locomotion.

\section{Urinary Bladder and Bowel management}

Bladder programmes stipulated during the rehabilitation period were continued in the medium high social class group $(95.7 \%)$, whilst in the lower social class the programme was abandoned by 43.5 per cent of patients. After the rehabilitation programme, 96 per cent of patients reached a 2-hour minimum period of continence following bladder training, but 86.4 per cent of those with upper neuron lesions and 4I.7 per cent with lower motor neuron lesion used condom collecting devices or diapers.

After hospitalisation 84 per cent of patients acquired bowel control but the programme was more often pursued in the higher social class patients.

\section{Occupation}

Eight per cent of patients were illiterate adults without a defined occupation and 88 per cent had an analysed occupation. Of the latter, I 2 per cent continued to develop the same activity, 46 per cent passed to develop educational activities or craftsmanship, and 42 per cent were unemployed or retired.

\section{Associated Data}

I. Pain. Thirty-six per cent of patients complained of pain below the level of the lesion, but this was not related to any common factor.

2. Spasticity. Fifty-two per cent of patients presented with spasticity requiring specific treatment.

3. Sexual. The information was not considered to be reliable.

\section{Conclusion}

I. This report indicates that where there is no comprehensive initial medical management there is a high incidence of urinary tract infection and stone, pressure sores, deformities and other complications, which increase the cost and extend the time of the rehabilitation process.

2. The effects of the socio-economic and cultural factors are felt in the acute phase and the rehabilitation process is successful mainly in patients who have a good socio-economic and cultural level.

3. In Brazil those factors which are not dependent on the cultural and socio-economic status of the patient such as sex, age, race, civil status, and the level of lesion, are the same as is reported in the data from the world literature.

4. These observations indicate that Brazil needs a large number of medical and paramedical staff trained and distributed in the different regions of the country to provide better management of the patient in the early phase as well as an increase in the number of rehabilitation centres. This programme will require considerable support from the Government if satisfactory rehabilitation programmes are to be developed. 


\section{RÉSUMÉ}

Cent malades paraplégiques sur un total de deux-cent trente neuf, ont été étudiés après, au moins, six mois en communauté; cette étude ayant pour but de mettre en question l'efficacité du programme de réhabilitation.

L'âge moyen des malades était de vingt-quatre ans et le niveau maximum de lésion était $\mathrm{T}_{\mathrm{I}}$. Tous les malades avaient subi un traitement intensif pendant 4,7 mois, en moynne. Les résultats obtenus ont été semblables à ceux de la littérature, mais, le bas niveau social-économique et l'absence d'orientation adéquate de traitement dans les hôpitaux, juste aprés lo traumatisme, furent des facteurs d'influence négative.

On conclut que: I-) Le Brésil a besoin de personnel médical et paramédical entrainé exclusivement pour soigner les malades durant leurs phases critiques et d'un plus grand nombre de Centres de Réhabilitation. 2-) Les paraplégiques ont beaucoup bénéficié des programmes de Réhabilitation. 3-) Le systéme de sécurité du Brésil devrait assumer, du point de vue financier, les programmes de Réhabilitation.

\section{ZUSAMMENFASSUNG}

Während eines 6 monatigen Aufenthaltes im Reabilitationszentrum wurden Ioo Patienten aus einer Gruppe von 239 zur Beobachtung und Auswertung der Reabilitationsbehandlung ausgewält. Das Durchschnittsalter der Patienten war 24 Jahre und die Segmenthöhe der Läsion lag bei $T I$.

Alle Patienten erhielten eine intensive Behandlung von durchschnittlich 4,7 Monaten. Die Ergebnisse stimmten mit denen in der Literatur angegebenen überein aber die schlechte sozial-ökonomische Lage und der Mangel an geeigneten Behandlungsmöglichkeiten in den Krankenhäusern bei der Einlieferung sind Faktoren die sich negativauf die Reabilitation auswirken.

Hierzu ist zusagen: I) Brasilien braucht dringend Ärzte und qualifiziertes Personal für die Bahanlung der Patienten im akuten Stadium sowie eine grössere Zahl von ReabilitationsZentren für die Weiterbehandlung. 2) Die Reabilitationstherapie ist von grosser Bedeutung für den Patienten. 3) Die Varantwortung in Bazug die Finanzierung der Reabilitationsbehandlung müsste die brasilianische Sozialversicherung übernehmen.

\section{BIBLIOGRAPHY}

Abrans, K. S. (I98I). The impact on marriages of onset paraplegia. Paraplegia, 19, 253-259.

Albin, M. S. (1980). The patient with spinal cord injury, pp. 186-263. Year Book Medical Publishers Inc., Chicago, Ill.

Alia, C. F. (1978). La infeccion urinaria en los lesionados medulares-relacion con la litiase. Revista Clinica Española, 149, pp. 585-587.

BEDBRooK, G. M. (198I). The care and management of spinal cord injury. SpringerVerlag-New York Inc.

BedBrook, G. M. (I975). Treatment of thoraco-lombar dislocation and fractures with paraplegia. Clinical Orthopaedics and Related Research, 112, 27-43.

BERRY, B. R. (1980). The late results of surgical treatment of pressure sores in paraplegics, British fournal of Surgery, 67, 473-474.

BRACKEN, M. B. (I980). Relationship between neurological and functional status after acute spinal cord injury: an epidemiological study. Fournal of Chronic Diseases, 33, I I 5-I 25.

BREgman, S. (1976). Sexual adjustment and feminine attractiveness among spinal cord injury women. Archives of Physical Medicine and Rehabilitation, 57, 448-450.

BRENA, S. F. (1979). Chronic pain states: their relationship to impairment and disability. Archives of Physical Medicine and Rehabilitation, 6o, 387-389.

BuRK, D. C. (1978). The early management of spinal cord injury. Medical fournal, I, I45-I 48.

BURR, R. G. (I978). Urinary calculi composition in patients with spinal cord lesions. Archives of Physical Medicine Rehabilitation, 59, 84-87.

Cambier, J. (I980). Manual de Neurologica. pp. 450-45I. Masson do Brasil.

CARTER JR. R. E. (I977). Etiology of traumatic spinal cord injury: statistics of more than I, IOO cases. Texas Medicine, 73, 6I-65.

Cibeira, J. B. (1970). Some conclusions on a study of 365 patients with spinal cord lesions. Paraplegia, 7, 248-254. 
Comarr, A. E. (1970). Sexual function among patients with spinal cord injury. Urology, 25, I $34-168$.

Crewe, N. M. (1979). Spinal cord injury: a comparison of preinjury and postinjury marriage. Archives of Physical Medicine and Rehabilitation, 6o, 252-256.

Davis, R. (1975). Pain and suffering following spinal cord injury. Clinical Orthopaedics and Related Research, 112, 76-80.

DIKE, A. E. (1974). Bacteriology of urinary tract infection in paraplegics. The Association of Clinical Pathologists 93rd General Meeting, fournal of Clinical Pathology, 27, 933.

Durkan, J. P. (1968). Menstruation after high spinal cord transection. American fournal of Obstetrics and Gynecology, 100, $52 \mathrm{I}-524$.

El Ghatit, A. Z. (1976). Marriage and divorce after spinal cord injury. Archives of Physical Medicine and Rehabilitation, 57, 470-472.

El Ghatit, A. Z. (I975). Outcome of marriage existing at the time of a male's spinal cord injury. Fournal of Chronic Diseases, 22, 383-388.

El Ghatit, A. Z. (1979). Education and training levels and employment of spinal cord injury patients. Archives of Physical Medicine and Rehabilitation, 6o, 405-406.

El Ghatit, A. Z. (1978). Variables associated with obtaining and sustaining employment among spinal cord injury males: a follow-up of 760 veterans. Fournal of Chronic Diseases, 3I, 363-369.

Former, J. V. (1976). Social and working conditions of our paraplegics. Paraplegia, I4, 74-80.

GiBson, C. J. (1978). Urinary output and incidence of $a$ cute urinary tract infection in patients with indwelling bladder catheters. Archives of Physical Medicine and Rehabilitation, 59, 17-20.

GolDBERG, R. T. (I973). Vocational adjustment, interests, work value and career plans of persons with spinal cord injuries. Scandinavian fournal of Rehabilitation Medicine, 5, 3-II.

GutmanN, L. (198I). Lesiones medulares-Tratamento global e investigacion, Ist. Spanish ed., Editorial Jims.

Higgins JR., G. E. (I979). Sexual response in spinal cord injured adults: a review of the literature. Archives of Physical Medicine and Rehabilitation, 8, I73-196.

HolDSWORTH, F. (1970). Fracture, dislocations and fracture-dislocations of the spine-a review article. The fournal of Bone and foint Surgery, 52-A, I 534-I55I.

Hussey, R. W. (I973). Spinal cord injury: requirements for ambulation. Archives of Physical Medicine and Rehabilitation, 54, 544-547.

Jackson, R. W. (1975). Surgical stabilization of the spine. Paraplegia, 13, 7I-74.

JACOBS, H. (1978). Medical complications and economic aspects of management of permanent spinal cord disease. Canadian Medical Association fournal, 118, 762-763.

Khella, L. (1977). IO I cases of spinal cord injury. American fournal of Physical Medicine, 56(I), 2 I-32.

Kurtzke, J. F. (1975). Epidemiology of spinal cord injury. Experimental Neurology, 48, I63-236.

Mas, G. R. (1970). Tratado de Reabilitação Médica, 2nd ed. vol. I, chapter XII, Editorial Cientifico Medica-Barcelona.

MeritT, J. L. (I976). Urinary tract infection causes and management, with particular reference to the patients with spinal cord injury: a review. Archives of Physical Medicine and Rehabilitation, 57, 365-373.

Montgomerie, J. Z. (I978). Pseudomonas colonization in patients with spinal cord injury. American fournal of Epidemiology, 108, 328-336.

Montoya, G. A. (I980). Effect of phenol on condution and synaptic transmission block. American fournal of Physical Medicine, 59, I84-195.

Nepomuceno, C. (I979). Pain in patients with spinal cord injury. Archives of Physical Medicine and Rehabilitation, 60, 605-608.

OHRY, A. (1978). Sexual function, pregnancy and delivery in spinal cord injury women. Gynecologic and Obstetric Investigation, 9, 28I-29I.

RichaRdson, R. R. (I98I). Prevalence and incidence of pressure sores in acute spinal cord injuries. Paraplegia, 19, 235-247.

Robinson, C. E. (1978). Decubitus ulcers in paraplegics-finantial implications. Canadian Fournal of Public Health, 69, 199.

STAUWFFER, E. S. (1978). Ambulation in thoracic paraplegia. The fournal of Bone and foint Surgery, 60-A, 823-824.

Suton, N. G. (I973). Injuries of the spinal cord-the management of paraplegia and tetraplegia. Butterworth \& Co. (publishers) Ltd. 
SweEt, W. H. (1975). Phantom sensation following intra-spinal injury. Neurochirurgia, 18, I 39-I 54 .

WAGNER JR., F. C. (I977). Management of acute spinal cord injury. Surgical Neurology, 7, 346-350.

WeISS, A. J. (I966). Sexual adjustment, identification and attitudes of patients with myelopathy. Archives of Physical Medicine and Rehabilitation, 4, 245-250.

WeLB, S. B. (I979). Spinal cord injury: epidemiologic implications, costs and patterns of care in 85 patients. Archives of Physical Medicine and Rehabilitation, 6o, 335-340.

Wilcox, N. E. (I972). Follow-up of 423 consecutive patients admitted to the Spinal Cord Centre, Rancho Los Amigos Hospital, Jan. I to Dec. 3 I, I 968. Paraplegia, I0, I I 5-I 22.

ZäCH, G. A. (1976). Treatment results of spinal cord injuries in the Swiss Paraplegic Centre of Basle. Paraplegia, 14, 58-65. 